\title{
THE EFFECTS OF PBL METHOD USING THE HYPERMEDIA TO THE STUDENTS' CRITICAL THINKING SKILL ON THE SOCIAL STUDIES SUBJECT
}

(Experimental Study in Nurul Fikri Integrated Islamic Middle School, Depok, Academic Year of 2012/2013)

\author{
SUPARNO \\ DICKY IRANTO \\ Dosen Fakultas Ekonomi Universitas Negeri Jakarta
}

\begin{abstract}
Education as human's process to gain knowledge is very important to create thinking skill for the human being. Related to that thing, implemented the learning with Problem Based Learning method which is the learning that is oriented to enhance the students' critical thinking skill. In the constructivism learning theory, the students should be able to construct the knowledge through problem solving so they got the truth which is useful for the existence.

This research is using the quasi experiment method with non-equivalent group design. The conclusion of this research shows that there is enhancement to the students' critical thinking skill significantly and suggested to use this method on another topic, schools gives the hypermedia facilities, and researching another learning competences.
\end{abstract}

Keywords: Problem Based Learning, Hypermedia, Critical Thinking Skill

\section{PENDAHULUAN}

Pendidikan sebagai proses
manusia memperoleh ilmu

pengetahuan sangat penting dalam membentuk kemampuan berpikir. Keberhasilan siswa dalam belajar akan mempengaruhi perkembangan peserta didik secara keseluruhan, sehingga masalah yang perlu dikaji adalah rendahnya kemampuan berpikir kritis siswa.

Melalui berpikir kritis siswa akan bertanya, mengaitkan ide, berpikir secara logis, mengetahui struktur suatu ilmu, baik dan buruk, benar dan salah, serta akibat suatu pemikiran. Konstruksi pengetahuan yang diperoleh dalam proses pembelajaran akan digunakan sebagai ide dan solusi dalam kehidupan.

Pembelajaran yang terjadi di sekolah masih bersifat konvensional, orientasi pembelajaran masih mengejar nilai dengan banyak mengerjakan latihan soal, 
inovasi pembelajaran yang dilakukan guru juga masih kurang. Pelaksanaan pembelajaran masih teacher oriented atau teks book oriented dimana guru masih sangat dominan dalam pembelajaran dan tidak terjadi improfisasi kreatifitas guru dalam mengajar. Efek dari pembelajaran tersebut adalah siswa akan pasif dan kemampuan berpikir kritisnya tidak berkembang.

Tantangan masa depan menuntut pembelajaran untuk lebih mengembangkan kemampuan berpikir kritis, karena pada hakekatnya tujuan akhir pendidikan adalah keterampilan berpikir. Oleh karena itu, strategi pembelajaran di sekolah tidak hanya mengajarkan konsep-konsep pokok saja, namun juga membangun kemampuan berpikir kritis siswa serta keterampilan memecahkan masalah agar dapat meningkatkan mutu pendidikan.

Guru harus mampu memilih dan menggunakan metode pembelajaran sesuai dengan materi yang dipilihnya. Salah satu metode pembelajaran yang mendorong siswa untuk mampu memecahkan masalah melalui proses berpikir, sehingga mampu mengkonstruksi makna pembelajaran bagi kehidupan adalah Problem Based Learning (PBL) yang memacu siswa untuk terlibat secara aktif dalam pembelajaran, menekankan pada proses dan pelatihan berulang yang akan bermuara pada penguasaan keahlian menghadapi dan memecahkan masalah. PBL merupakan salah satu alternatif metode pembelajaran yang memungkinkan siswa dapat mengembangkan kemampuan berpikir kritis, karena di dalam PBL siswa dihadapkan pada masalah sebagai stimulus yang menjadi fokus dan harus dipecahkan dalam aktivitas belajar.

Dalam PBL siswa dipacu untuk terlibat secara aktif mencari makna dalam pembelajaran sehingga mampu diterapkan pada kehidupan yang akan datang. Pembelajaran tersebut berlangsung secara terpola melalui proses yang bermuara pada penguasaan keahlian dalam memecahkan masalah.

Dalam pembelajaran kita mampu mengamati siswa yang fokus memperhatikan pembelajaran serta yang sekedar hadir dikelas. Dalam kajian Attention Deficit Hyperactivity Disorder (ADHD), James Le Fanu (2008:195) menyampaikan sebagai berikut: "Secara umum ada tiga perilaku yang bisa dihubungkan dengan ADHD ini, inatentif (tidak memperhatikan) atau distraktif (mudah terusik), impulsif (semaunya sendiri) dan, hiperaktif'. Kita mampu mengarahkan siswa kita untuk aktif belajar mengoptimalkan perhatiannya dengan media pembelajaran.

Penggunaan metode pembelajaran yang tepat diharapkan akan mampu mempengaruhi interaksi pembelajaran dan pola berpikir siswa yang pada akhirnya akan mempengaruhi keberhasilan pembelajaran.

Guru dalam pembelajaran mempersiapkan Rencana Pelak- 
sanaan Pembelajaran (RPP) yang didalamnya terdapat metode dan media. Dalam pembelajaran konvensional guru dan buku adalah sumber dan media utama, tetapi pembelajaran konstruktivisme membutuhkan penguasaan guru terhadap media dan pembelajaran dengan metode yang mampu mengantarkan siswa pada proses berpikir dan memecahkan masalah. Media yang digunakan guru dalam menyampaikan pesan mampu menghadirkan pembelajaran lebih banyak kepada siswa melintasi batas waktu, tempat, dan menghadirkan secara nyata fakta dan masalah dalam pembelajaran.

Penelitian yang dilakukan Bobbi De Porter (Niken Ariani dan Dany Haryanto, 2010: 6)Penggagas Quantum learning mengungkapkan, manusia dapat menyerap suatu materi sebanyak $70 \%$ dari apa yang dikenakannya, 50\% dari apa yang didengar dan dilihat (audio visual), dan $30 \%$ dari yang dilihatnya, dari informasi $20 \%$ dan dari yang dibaca $10 \%$. Dengan media pembelajaran diharapkan mampu meningkatkan kesadaran belajar berbasis audio visual.

Hypermedia akan digunakan dalam metode PBL ini untuk meningkatkan kemampuan berpikir kritis siswa dengan mengoptimalkan sarana dan prasarana sekolah yang didukung adanya ruang e-learning dan multimedia.

\section{Rumusan Masalah}

Masalah dalam penelitian ini
sebagai dirumuskan sebagai
berikut:

1. Apakah terdapat perbedaan kemampuan berpikir kritis siswa antara sebelum dan sesudah perlakuan pada kelas yang menggunakan metode problem based learning (PBL) dengan hypermedia (kelas eksprimen)?

2. Apakah terdapat perbedaan kemampuan berpikir kritis siswa antara sebelum dan sesudah perlakuan pada kelas yang menggunakan metode diskusi dengan multimedia (kelas kontrol)?

3. Apakah terdapat perbedaan peningkatan kemampuan berpikir kritis siswa pada kelas yang menggunakan metode problem based learning (PBL) menggunakan hypermedia (kelas eksprimen) dengan kelas yang menggunakan metode diskusi dengan multimedia (kelas kontrol)?

\section{DESKRIPSI TEORITIS}

\section{Kemampuan Berpikir Kritis}

Berpikir kritis termasuk proses berpikir tingkat tinggi, karena pada saat mengambil keputusan atau menarik kesimpulkan menggunakan kontrol aktif, yaitu reasonable, reflective, responsible, dan skillful thinking. Seperti yang sampaikan Livingston (1997) salah satu ciri dari berpikir tingkat tinggi adalah proses yang melibatkan kontrol aktif selama proses kognitif itu berlangsung.

Keterampilan berpikir dikelompokkan menjadi keterampilan berpikir dasar dan keterampilan berpikir tingkat tinggi. Menurut Costa (1985) yang termasuk kete- 
rampilan berpikir dasar meliputi kualifikasi, klasifikasi, hubungan variabel, tranformasi, dan hubungan sebab akibat. Sedangkan keterampilan berpikir kompleks meliputi problem solving, pengambilan keputusan, berpikir kritis dan berpikir kreatif.

Jadi seseorang yang berpikir kritis maka ia biasa mengajukan pertanyaan yang tepat, menggabungkan informasi yang relevan, secara efesien dan kreatif menyusun informasi, mempunyai nalar yang masuk akal atas informasi yang dimiliki, dan kesimpulan kesimpulannya konsisten serta dapat dipercaya sehingga dapat dimanfaatkan untuk kehidupan manusia dan bisa memetik keberhasilan.

Berpikir kritis adalah pengambilan keputusan secara rasional atas apa yang diyakini dan dikerjakan. Menurut Michael Scriven and Richard Paul (Ebiendele Ebosele Peter, 2012:1)mengatakan: Critical thinking is the intelectually disciplined process of actively and skillfully conceptualizing, applying, analyzing, sinthesizing, and/or evaluating information gathered from orgenerated by observation, experience, reflection, reasoning, or communication, asguide to belief and action.

Tampak dari definisi tersebut bahwa berpikir kritis melibatkan aspekaspek kognitif semisal aplikasi, analisis, sintesis, dan evaluasi.

Berpikir kritis merupakan aspek penting dan topik yangvital dalam pendidikan modern sehingga para pendidik tertarik untuk mengembangkan berpikir kritis kepada siswa. Dengan kemampuan berpikir kritis siswa akan mengembangkan pengetahuan dan pola pikirnya interpretasi, analisis, evaluasi, dan berargumen.

$$
\text { Menurut Faccione (1998) }
$$

mengacu pada konsensus para ahli dalam American Philosopical Association pada tahun 1990 memperkenalkan lima langkah dalam proses berpikir yaitu: interpretasi, analyisis, evaluasi, keahlian menyimpulkan, berargumen dan berefleksi. Kemampuan berpikir kritis berdasarkan konsensus yang dihadiri 46 ahli dari Universitas Terkemuka yang dilakukan oleh American Philosophical Association mereka sampai pada konsensus berkenaan dengan berpikir kritis yang diwujudkan dalam pernyataan sebagai berikut:

Kita memahami berpikir kritis sangatlah bertujuan, melakukan penilaian sendiri yang menghasilkan penafsiran, analisis, evaluasi, dan kesimpulan penjelasan berdasarkan bukti, konsep, metode, criteria atau pertimbangan kontekstual yang menjadi dasar penilaian. Berpikir kritis merupakan hal mendasar sebagai alat penemuan. Dengan demikan berpikir kritis merupakan kekuatan yang membebaskan dalam pendidikan dan merupakan sumber daya yang berharga dalam kehidupan sipil seseorang. Berpikir kritis tidak bisa disamakan dengan berpikir dengan baik sebab berpikir kritis merupakan fenomena yang meralat dan meresap dalam hidup manusia. Pemikir kritis yang ideal 
adalah yang terbiasa mempertanyakan, penuh pengetahuan, terpercaya pemikirannya, berpikir terbuka, lentur, adil dalam menilai, jujur dalam menghadapi bias pribadi, bijaksana dalam menilai, ikhlas untuk mempertimbangkan kembali, jelas terhadap issu, tertata dalam masalah yang kompleks, rajin mencari informasi yang relevan, masuk akal dalam memilih kriteria, terfokus pada penemuan, dan ajeg dalam menemukan hasil subjek yang rinci dan memungkinkan iklim penemu-an. Jadi, mendidik pemikir kritis ditujukan pada idealisme ini yaitu dengan mengkombinasikan pe-ngembangan keahlian berpikir kritis dengan menanamkan disposisi yang secara konsisten menghasilkan wawasan yang bermanfaat dan yang menjadi dasar bagi masyarakat rasional dan demokrasi. Facione, P. A. (1998:2)

Berdasarkan pemaparan pendapat para ahli dalam mendifinisikan kemampuan berpikir kritis di atas dapat diterjemahkan dalam tabel sebagai berikut:

\section{Konsensus Para ahli terhadap Definisi Berpikir Kritis}

\begin{tabular}{|l|l|}
\hline Penafsiran & $\begin{array}{l}\text { 'memahami dan mengungkapkan arti atau pentingnya perbedaan } \\
\text { pengalaman, situasi, data, kejadian, penilaian, penemuan, keyakinan } \\
\text { aturan, prosedur atau criteria' }\end{array}$ \\
\hline Analisis & $\begin{array}{l}\text { 'mengidentifikasi kecenderungan dan kesimpulan aktual hubungan } \\
\text { antara pernyataan, pertanyaan, konsep, deskripsi atau bentuk lain } \\
\text { representasi yang dimasudkan untuk menyatakan keyakinan, } \\
\text { penilaian, pengalaman, pemikiran, informasi dan pendapat. }\end{array}$ \\
\hline Evaluasi & $\begin{array}{l}\text { 'untuk menilai kredibilitas pernyataan atau represnetasi lain yang } \\
\text { penting atau peggambaran persepsi orang, pengalaman, situasi, } \\
\text { penilaian, keyakinan, atau pendapat; dan untuk menilai kekuatan logis } \\
\text { kesimpulan aktual atau kecenderungan hubungan antar } \\
\text { pernyataan,deskripsi, pertanyaan atau bentuk representasi lainnya }\end{array}$ \\
\hline Kesimpulan & $\begin{array}{l}\text { 'untuk mengnali dan meyakini elemen yang dibutuhkan untuk menarik } \\
\text { kesimpulan yang masuk akal; untuk membentuk hipotesis dan dan } \\
\text { perkiraan; untuk memperhitungkan informasi relevan dan } \\
\text { memperhitungkan konsekuensi yang mengalir dari data, pernyataan, } \\
\text { prinsip, bukti, penilaian, keyakinan, pendapat, konsep, deskriopsi, } \\
\text { pertanyaan, atau bentuk lain representasi. }\end{array}$ \\
\hline Penjelasan & $\begin{array}{l}\text { 'untuk menyatakan hasil pemikiran; untuk mengesahkan pemikiran } \\
\text { dalam kerangka bukti, konsep, method, criteria dan pertimbangan } \\
\text { kontekstual yang menjadi dasar pemikiran seseorang; dan untuk } \\
\text { menyajikan pemikiran orang dalam bentuk argument yang kuat. }\end{array}$ \\
\hline
\end{tabular}

Sumber: Marrapodi Jean (2003:7)

Berdasarkan kajian di atas
maka pengertian kemampuan
berpikir kritis adalah suatu

kemampuan berpikir tingkat tinggi yang tujuannya untuk mengkaji sebuah situasi, fenomena, 
pertanyaan, atau masalah untuk mendapatkan sebuah hipotesis atau kesimpulan sebagai proses pengambilan keputusan secara

\section{Problem Based Learning (PBL)}

PBL sebagai metode pembelajaran dimana siswa belajar melalui pemecahan masalah difasilitasi yang berpusat pada masalah kompleks yang tidak memiliki jawaban yang benar disampaikan oleh Hmelo-Silver (Savery, J. R. 2006:12) bahwa " $P B L$ as an instructional method in which students learn through facilitated problem solving that centers on a complex problem that does not have a single correct answer", sedangkan menurut Duch, Groh, \& Allen (Watson,G. 2002: 1) menyampaikan PBL sebagai metode pembelajaran yang menantang siswa untuk "belajar untuk belajar," bekerja sama dalam kelompok untuk mencari solusi untuk masalah seperti pernyataannya sebagai berikut: 'Problem-based learning $(P B L)$ is an instructional method that challenges studentsto "learn to learn," working cooperatively in groups to seek solutions to problems'.

Dalam metode pembelajaran PBL memberikan keterampilan khusus, dan merupakan pembelajaran berbasis konstruktivisme. Dalam pandangannya tentang metode PBL Taplin (Baturay.M.H, Bay.O.F, 2009: 44) mengemukakan bahwa PBL merupakan metode pembelajaran yang inovatifdidukung oleh teori pembelajaran sosial dan pendekatan konstruktivis. Ada rasional atas apa yang diyakini dan dikerjakan secara nyata melalui aspek penafsiran, analisis, evaluasi, kesimpulan dan penjelasan.

banyak alasan mengapa PBL diterapkan dengan sukses sebagai metode pembelajaran.Alasan yang paling mendesak adalah bahwa tuntutan dunia kerja saat ini sebagian besar mengajukan kesempatan untuk lulusan yang dilengkapi dengan tempat kerja khusus keterampilan yang diperlukan. Kingsland (Baturay.M.H, Bay.O.F, 2009: 44) menyampaikan bahwa dalam lingkungan PBL, siswa merasa perlu untuk belajar pengetahuan baru sebelum mereka dapat memecahkan masalah, karena itu, keterampilan tingkat tinggi pemikiran mereka direkam. Hal tersebut disamapaikan sebagai berikut: 'In a PBL environment, students feel the need to learn new knowledge before they can solve a problem; therefore, their higher level thinking skills are tapped".

Dalam pandangannya tentang metode PBL Brooke, S. L. (2006:1) menyampaikanbahwa: "Problem-based learning (PBL) is an instructional method that challenges students to actively learn by working cooperatively in groups to seek solutions to real world problems". Pembelajaran berbasis masalah (PBL) merupakan metode pembelajaran yang menantang siswa untuk aktif belajar dengan bekerja sama dalam kelompok untuk mencari solusi untuk masalah dunia ."PBL is a learner-centered instructional method that enhances students' ability to analyze, 
synthesize, and evaluate problems". Ramsay, J. dan Sorrell, E. (2006:2). PBL adalah pembelajar berpusat pada metode pengajaran yang meningkatkan kemampuan siswa untuk menganalisis, mensintesis, dan mengevaluasi masalah.

Ramsay, J. dan Sorrell, E. (2006) menyampaikan PBL sebagai metode instruksional dalam pembelajaran dalam pandangannya sebagai berikut:

$P B L$ is an instructional method that utilizes real problems as the primary pathway of learning. The problems used in PBL activities are complex and rooted in real-world situations. They are current and reflect a typical problem encountered in the work environment specific to a particular discipline.

Diterjemahkan menjadi PBL merupakan metode instruksional yang memanfaatkan masalah nyata sebagai jalur utama belajar. Masalah yang digunakan dalam PBL kegiatan yang kompleks dan berakar pada situasi dunia nyata.Mereka saat ini dan mencerminkan masalah khas yang dihadapi di lingkungan kerja yang spesifik untuk disiplin tertentu.

Berdasarkan kajian di atas Problem Based Learning (PBL) didefinisikan sebagai metode pembelajaran yang menjadikan permasalahan yang berkaitan dengan topik-topik dalam kurikulum sebagai titik tolak dalam proses pembelajaran mandiri dan kolaboratif. Tahapan dalam PBL terdiri dari langkah - langkah sebagai berikut: (a) mengorientasikan siswa pada masalah; (b) mengorganisasikan siswa untuk belajar; (c) membimbing pemeriksaan individual atau kelompok;(d) mengembangkan dan menyajikan hasil karya; (e) menganalisis dan mengevaluasi proses pemecahan masalah.

PBL

mengembangkan pembelajaran berpusat pada siswa dan yang pemecahan masalah secara efektif dan kritis melalui lima tahap sebagai berikut:

Teori belajar konstruktivisme menyatakan bahwa siswa harus menemukan sendiri dan mentransformasikan informasi kompleks, mengecek informasi baru dengan aturan lama dan merevisinya apabila aturan - aturan itu tidak berlaku dan tidak lagi sesuai. Siswa harus mampu memecahkan masalah, mengemukakan ide-ide, serta mencari kebenaran. Membangun sendiri pengetahuannya tanpa harus bergantung pada guru adalah salahsatu penekanan pembelajaran konstruktivisme. Dalam pembelajaran ini guru hanya sebagai fasilitator yang mengatur memberikan kemudahan bagi siswa untuk belajar. 
Tahap-tahap Pengembangan Pembelajaran Berbasis Masalah

\begin{tabular}{|c|l|l|}
\hline $\begin{array}{c}\text { Fa } \\
\text { se }\end{array}$ & \multicolumn{1}{|c|}{ Indikator } & \multicolumn{1}{c|}{ Perilaku Guru } \\
\hline 1 & $\begin{array}{l}\text { Orientasi siswa } \\
\text { pada masalah }\end{array}$ & $\begin{array}{l}\text { Guru menjelaskan tujuan pembelajaran, } \\
\text { menjelaskan logistik yang dibutuhkan, } \\
\text { memotivasi siswa untuk terlibat pada } \\
\text { aktivitas penyelesaian masalah }\end{array}$ \\
\hline 2 & $\begin{array}{l}\text { Mengorganisasi } \\
\text { siswa untuk } \\
\text { belajar }\end{array}$ & $\begin{array}{l}\text { Guru membantu siswa mengidentifikasi } \\
\text { dan mengorganisasikan tugas belajar } \\
\text { yang berhubungan dengan masalah }\end{array}$ \\
\hline 3 & $\begin{array}{l}\text { Membimbing } \\
\text { investigasi } \\
\text { individual maupun } \\
\text { kelompok }\end{array}$ & $\begin{array}{l}\text { Guru mendorong siswa untuk } \\
\text { mengumpulkan informasi yang sesuai, } \\
\text { melaksanakan observasi untuk } \\
\text { menyelesaikan masalah }\end{array}$ \\
\hline $\begin{array}{l}\text { Mengembangkan } \\
\text { dan menyajikan } \\
\text { hasil karya }\end{array}$ & $\begin{array}{l}\text { Guru membantu siswa dalam } \\
\text { merencanakan dan menyiapkan karya } \\
\text { yang sesuai seperti laporan dan } \\
\text { membantu mereka untuk berbagi tugas } \\
\text { dengan temannya. }\end{array}$ \\
\hline 5 & $\begin{array}{l}\text { Menganalisis dan } \\
\text { mengevaluasi } \\
\text { proses } \\
\text { penyelesaian } \\
\text { masalah }\end{array}$ & $\begin{array}{l}\text { Guru membantu siswa untuk melakukan } \\
\text { refleksi atau evaluasi terhadap } \\
\text { investigasi dan proses yang mereka } \\
\text { lakukan }\end{array}$ \\
\hline
\end{tabular}

Menurut pengajaran John Dewey (Trianto, 2011:17) metode reflektif didalam memecahkan masalah, yaitu suatu proses berpikir aktif, hati hati. Pengalaman siswa dalam pembelajaran akan terbentuk dengan adanya alternatif pilihan dan resiko yang diambil dari suatu keputusan. Siswa akan menjadi seorang pemikir kritis dan mencari kebenaran dengan menjadi pengambil resiko terbaik atas suatu keputusan yang diambil dalam menyelesaikan suatu masalah hidup.

\section{Hypermedia sebagai Media Pembelajaran} Media pembelajaran meliputi segala sesuatu yang dapat membawa pesan dan informasi yang disampaikan pengajar sebagai komunikasi kepada siswa dalam menyampaikan materi pembelajaran, sehingga dapat meningkatkan pengetahuan, motivasi, daya pikir dan pemahaman peserta didik terhadap materi pembelajaran yang disampaikan.

Pembelajaran dengan menggunakan media mengundang perhatian siswa dalam belajar. Hal 
tersebut mampu mengambil perhatian siswa sehingga siswa akan aktif. Eric Jensen (2011:75) menyampaikan pendapatnya sebagai berikut: "Dapatkan perhatian otak dengan pergerakan, kontras, dan perubahan warna. Sistem visual kita diciptakan untuk menaruh perhatian pada unsur unsur tersebut, karena mereka memiliki potensi memberi sinyal bahaya" Dengan warna, animasi, audio-visual yang mampu kita tampilkan melalui media pembelajaran, akan lebih menarik siswa mempelajari materi yang kita sampaikan dikelas.

Hypermedia sebagai bagian dari pembelajaran berbasis komputer (computer based system) memanfaatkan hiperterteks dengan merangkum berbagai media dengan adanya penghubung (link) dari pengguna yang dihubungkan dengan nodes meliputi video, suara, musik, teks, animasi, film, image dan data. Hal tersebut disampaikan oleh Blanchard dan Rotenberg (Munir dan Halimah Badioze Zaman, 1999:5) sebagai berikut:

Hypermedia adalah gabungan berbagai media yang dikawal oleh hiperteks. Hypermedia dapat merangkumi pelbagai media: video, suara, muzik, teks, animasi, film, grafik dan imej. Dalam hypermedia ada dua konsep dasar yang menjadi ciri khusus yaitu penghubung (link) dan yang dihubungkan (nodes). Nodes adalah bahagianbahagian dari sumber maklumat yang ada dalam hypermedia yang meliputi ; video, suara, musik, teks, animasi, film, grafik, imej dan data.
Sedangkan link adalah penghubung atau yang membuat hubungan antara nodes dengan pengguna. Hiperteks dalam hypermedia berfungsi sebagai link. Jadi nodes tidak mempunyai arti apa-apa dalam hypermedia tanpa adanya peranan hyperteks sebagai link.

\section{METODE PENELITIAN}

Penelitian ini merupakan penelitian kuasi eksperimen atau "eksperimen semu" yang terdiri dari dua kelompok penelitian yaitu kelas eksperimen melakukan pembelajaran dengan metode Problem Based Learning (PBL) menggunakan hypermedia dan kelas kontrol melakukan pembelajaran konvensional, desain dalam penelitian ini berbentuk desain Nonequivalent (Pretest and Posttest) Control Group Design. Langkah-langkah dalam desain ini sama dengan pretestposttest experimental control group design.

Desain Qnasi Eksperimen
\begin{tabular}{|l|l|l|l|}
\hline KELONPOK & PRE-TEST & PERLAKUAN & POST-TEST \\
\hline Eksperimen & $0_{1}$ & X & $0_{2}$ \\
\hline Kontrol & $0_{1}$ & - & $0_{2}$ \\
\hline
\end{tabular}

McMillan \& Schumacher (2001), Fraenkel \& Walen (1993)

Keterangan :

01 = Tes awal pada kelomppok eksperimen dan kelompok kontrol

$\mathrm{O} 2$ = Tes akhir pada kelompok eksperimen dan kelompok kontrol

$\mathrm{X}=$ Perlakuan dengan menggunakan Pembelajaran Metode Problem Based Learning dan Hiper Media 
Populasi dalam penelitian ini adalah seluruh Siswa SMPIT Nurul Fikri, Kota Depok tahun pelajaran 2012/2013 yang berjumlah 423 siswa. Sampel penelitian ini adalah siswa kels 8 semester 1 SMPIT Nurul Fikri. Sampel pada penelitian ini terdiri dari dua kelas, yaitu kelas eksperimen dengan metode PBL menggunakan hypermedia dan sebagai kelas kontrol dengan pembelajaran konvensional. Penentuan sampel dilakukan dengan menggunakan teknik purposive sampling sebanyak 2 dari 12 kelas dan dipilih kelas 8A dan 8B dengan pertimbangan siswa kelas 8 telah mendapat materi prasyarat sehingga dapat dijadikan dasar untuk melaksanakan tindakan pembelajaran sesuai dengan yang dikehendaki dalam penelitian ini, dan kemampuan kelas 8 yang diperkirakan telah dapat mengikuti proses pembelajaran yang akan diberikan. Dari kedua kelas tersebut ditentukan kelas $8 \mathrm{~A}$ yang terdiri dari 36 orang siswa sebagai kelas eksperimen yang mendapat pembelajaran dengan metode $\mathrm{PBL}$ menggunakan hypermedia, sedangkan kelas 8B sebagai kelas kontrol terdiri dari 35 orang mahasiswa yang mendapat pembelajaran dengan metode diskusi menggunakan multimedia.

\section{DESKRIPSI HASIL PENELITIAN}

Data hasil tes kemampuan berpikir kritis siswa terdiri dari pretes dan postes yang diperoleh melalui tes tertulis berbentuk pilihan gandadiperoleh angka signifikansi padapretest 1 adalah 0,324 dan
0,323 . Pretest tahap 2 adalah 0,855 serta pretest tahap 3 adalah 0,513 dan 0,512maka kemampuan awal berpikir kritis siswa kedua kelas (eksperimen dan kontrol) adalah sam

Setelah diberikan pembelajaran pada kelas eksperimen menggunakan metode problem based learning dengan hypermedia dan kelas kontrol menggunakan metode diskusi dengan multimedia, siswa diberikan soal tesakhir (posttest) diperoleh angka signifikansi pada postest 1 adalah 0,020 , postest tahap 2 adalah 0,001 serta postest tahap 3 adalah 0,003. Oleh karena angka signifikansi lebih kecil dari 0,05, maka kemampuan berpikir kritis siswa dalam skala pengukuran akhir kedua kelas (eksperimen dan kontrol) adalah terdapat perbedaan secara signifikan.

$$
\text { Setelah mengetahui }
$$

kemampuan awal dan kemampuan akhir kemampuan berpikir kritis siswa pada kelas eksperimen dan kelas kontrol melalui analisis pretest dan postest di atas, selanjutnya adalah membandingkan kemampuan awal dan kemampuan akhir dari masing-masing kelas diperoleh bahwa kemampuan berpikir kritis siswa kelas eksperimen dan kelas kontrol sama-sama terjadi perubahan yang signifikan namun perubahan pada kelas eksperimen jauh lebih besar dari kelas kontrol.

Untuk mencari perbedaan peningkatan (N-Gain) kemampuan berpikir kritis siswa diperoleh dengan cara membandingkan $n$ gain kelas kontrol dengan n-gain 
pada kelas eksperimen. Didapat bahwa masing-masing kelas, baik kelas eksperimen maupun kelas kontrol terjadi peningkatan kemampuan berpikir kritisnya pada test tahap 1 kelas eksperimen peningkatan yang terjadi sebesar $0,43(43 \%)$, pada test tahap 2 kelas eksperimen peningkatan yang terjadi sebesar 0,42 (42\%), pada test tahap 3 kelas eksperimen peningkatan kemampuan berpikir kritis siswa terjadi sebesar 0,52 $(52 \%)$.

\section{KESIMPULAN}

Berdasarkan hasil temuan penelitian, analisis dan pembahasan yang telah dilakukan pada mengenai pembelajaran dengan metode problem based learning menggunakan hypermedia pada SMP Islam Terpadu Nurul Fikri Kota Depok diperoleh beberapa kesimpulan yang merupakan jawaban atas pertanyaan-pertanyaan yang diajukan dalam rumusan masalah. Kesimpulan-kesimpulan tersebut adalah:

1. Pembelajaran dengan metode problem based learning (PBL) menggunakan hypermedia mampu meningkatkan kemampuan berfikir kritis siswa dalam pembelajaran Ilmu Pengetahuan Sosial. Hal tersebut menunjukkan pembelajaran PBL menggunakan hypermedia adalah metode yang tepat dipilih guru dalam pembelajaran untuk meningkatkan kemampuan berfikir kritis siswa.

2. Pembelajaran dengan metode diskusi menggunakan multimedia mampu meningkatkan kemampuan berfikir kritis siswa dengan tingkat signifikansi rendah. Hal tersebut menunjukkan kemampuan berfikir kritis siswa belum berhasil ditingkatkan dengan metode diskusi menggunakan multimedia.

3. Pembelajaran dengan metode problem based learning (PBL) menggunakan hypermedia lebih baik dibandingkan pembelajaran menggunakan metode pembelajaran yang lain dalam meningkatkan kemampuan berfikir kritis siswa. Hal inimenunjukkan bahwa pembelajaran dengan metode problem based learning (PBL) menggunakan hypermedia yang telah dilaksanakan sudah berhasil diterapkanpada siswa untuk aspek kemampuan berpikir kritis, walaupunpeningkatan kemampuan berfikir kritis yang diperoleh siswa masih dalam kategori sedang.

\section{Saran}

Beberapa saran atau rekomendasi yang dapat dikemukakan:

1. Kemampuan berpikir kritis siswa dalam pembelajaran IPS dapat ditingkatkan dengan pembelajaran yang menggunakan metode problem based learning dengan hypermedia oleh karena itu diperlukan pengembangan yang lebih jauh untuk topik permintaan, penawaran dan harga keseimbangan dalam pembelajaran IPS.

2. Dalam pembelajaran dengan metode PBL menggunakan hypermedia perlu adanya 
penguasaan media oleh siswa dan guru. Selain itu sekolah perlu menyediakan fasilitas ruang e-learning yang mampu mengakomodasi hypermedia dengan koneksi internet secara on-line.

3. Kepada peneliti selanjutnya dapat melakukan penelitian tentang metode PBL menggunakan hypermedia untuk meningkatkan kompetensi belajar yang lain.

\section{DAFTAR PUSTAKA}

Ariani, N dan Haryanto, D. (2010). Pembelajaran Multi Media di Sekolah: Pedoman Pelaksanaan Pembelajaran Inspiratif, Konstruktif, dan Prospektif. Jakarta: Prestasi Pustaka Publisher

Baturay.M.H, Bay.O.F. (2009). "The effects of problem-based learning on the classroom community perceptions and achievement of web-based education students" Computers \& Educationan International Journal.55,43-52.

Brooke, S. L. (2006). Using the Case Method to Teach Online Classes: Promoting Socratic Dialogue and Critical Thinking Skills. International Journal of Teaching and Learning in Higher Education, Volume 18, (2), 142-149. Avaliable: http://www.isetl.org/ijtlhe/pdf/lJ TLHE58.pdf (17 Mei 2012)

Costa and Pressceisen. (1985). Developing Minds: A Resource
Book for Teaching Thinking. Alexandria: ASCD.

Facione, P. A. (1998). Critical Thinking: $A$ Statement of Expert Consensus for Purposes of Educational Assessment and Instruction"The Delphi Report". (Online). Available at: http://assessment.aas.duke.ed u/documents/Delphi_Report.pd $f($ Mei 10, 2012)

Fanu, J. L. (2008).Deteksi dini masalah masalah Psikologi anak dan proses terapinya. Jogjakarta: think

Jean, M. (2003). Critical Thinking And Creativity an Overview and Comparison of The Theories. (Online). Tersedia: http://www.applestar.org/capella /CRITICAL\%20THINKING\%20A ND\%20CREATIVITY.pdf (4 Juli 2012)

Jensen, E. (2011). Pembelajaran Berbasis Otak: Brain Based Learning. Jakarta: PT Indeks

Livingston, J.A.

(1997). Metacognition. [Online]. Tersedia: http://www.gse. buffalo.edu/fas/shuell/cep564/ Metecog.htm. [23 Januari 2012].

Peter, Ebiendele Ebosele (2012). "Critical thinking: Essence for teaching mathematics and mathematics problem solving skills". African Journal of Mathematics and Computer Science Research Vol. 5(3), pp. 39-43, University of louisville. (Online) Tersedia: http://louisville.edu/ideastoactio 
n/what/critical-thinking/what-iscritical-thinking (4 Juli 2012)

Ramsay, J. and Sorrell, E. (2006). Problem-Based Learning: $A$ Novel Approach to Teaching Safety, Health and Environmental Courses. In Journal of SH\&EResearch (Online), Vol. 3, ( 2), Page 8. Avaliable:

http://www.asse.org/academicsj ournal/archive/vol3no2/06summ er_ramsay.pdf (17 Mei 2012)

Savery, J. R. (2006). "Overview of Problem-based

Learning:Definitions and Distinctions". The Interdisciplinary Journal of Problem-based Learning (Online). Volume 1, (1), Page: 9 - 20. Avaliable: http://www.tne.uconn.edu/Cas e\%20Method/Savery,\%202006 .pdf (17 Mei 2012)

Trianto, (2011). Pembelajaran Inovatif berorientasi Konstruktivistik. Konsep, landasan teoristis - praktis dan implementasinya. Jakarta: Prestasi Pustaka Publisher
Watson,G. (2002, 30 April). Using Technology to Promote Success in PBL Courses. A Publication of Michigan Virtual University (Online), Page 5. Tersedia:

http://ts.mivu.org/default.asp?s how=article\&id=969. (17 Mei 2012)

Zaman, M. H. B. (1999). Aplikasi Multimedia dalam Pendidikan. Jurnal BTP 1 (Online). Volume 1 (1), Hal: 1 - 16. Tersedia Online:

http://file.upi.edu/Direktori/FPM IPA/PRODI._ILMU_KOMPUTE $\mathrm{R} / 1966032520011 \overline{21}$ MUNIR/Artikel_TIK/Aplikasi_M ultimedia_Dalam_Pendidikan_ 2.pdf. (10 Mei 2012) 